\title{
Pengaruh Identitas Brand Dan Strategi Penjualan Burger King Terhadap Keputusan Pembelian Konsumen
}

\author{
Amelda Pramezwary ${ }^{1}$, Juliana $^{2}$, Billy Eagan ${ }^{3}$, Feidora Jovanca Putri ${ }^{4}$, Steven Setiadi ${ }^{5}$ \\ 1,2,3,4,5 Fakultas Pariwisata, Universitas Pelita Harapan, Indonesia \\ Email : Juliana.stpph@uph.edu
}

Cara Sitasi: Amelda P, Juliana, Billy E, Feidora Jovanca P, Steven S (2021), Pengaruh Identitas Brand Dan Strategi Penjualan Burger King Terhadap Keputusan Pembelian Konsumen (2021) 21 (1), 10- 18 Retrieved from https://doi.org/10.31294/jc.v19i2

\begin{abstract}
Abstrak - The pandemic period in 2020 has had a major impact on various sectors. no exception to the business sector that is growing rapidly such as the fast food business. This rapid development shows the growing intensity of competition in the fast food business. such as Burger King, AW, McDonald's, KFC, and so on. because of this, business owners must pay more attention to the desires of consumers who are diverse, change fast, and of course have different satisfaction values. The purpose of this study was to determine the effect of the Burger King brand identity and sales strategy on consumer purchasing decisions during the Covid 19 pandemic. The sample consisted of 105 respondents who had answered a questionnaire about the Burger King brand and the marketing strategy undertaken by Burger King. The samples that have been received are then analyzed for their answers, starting with descriptive analysis, basic statistics, and regression. After this analysis, the results obtained in the form of burger king brand identity have a significant effect, and the burger king sales strategy also has a significant effect. This shows that consumer purchasing decisions are influenced by brand identity and strategy
\end{abstract}

Key words: Brand Identity, Sales Strategy, Consumer Purchasing Decisions

\section{PENDAHULUAN}

Tahun 2020 merupakan tahun yang cukup sulit dilewati dimana terjadi pandemi yang melanda seluruh dunia. diawali dengan permasalahan kesehatan yang kita kenal dengan Covid 19, keadaan ini membuat situasi baru di seluruh penjuru dunia. Virus ini adalah virus berbahaya yang perkembangannya begitu pesat. Virus tersebut dapat ditularkan melalui sistem pernapasan hingga menyebabkan korban yang terkena penyakit tersebut sesak napas, demam dan penyakit pernapasan lainnya. Virus tersebut terdapat di droplet penderita kemudian menularkan kepada orang lain. Pencegahan penyebarannya yaitu dengan mengurangi kerumunan massa, menjaga jarak, mencuci tangan menggunakan sabun, dan memakai masker untuk mencegah droplet masuk melalui mulut atau hidung (Tim COVID-19 IDAI, 2020). Di Indonesia sendiri, Wabah virus corona terus mengalami peningkatan setiap harinya. Covid-19 ini berdampak pada banyak sektor, seperti dunia pariwisata, restoran, hotel, penjual makanan siap saji, kedai-kedai kerajinan, buruh, petani, pekerja harian semua kena dampaknya. para pekerja disektor pariwisata agar mengambil langkah mitigasi dengan secepat-cepatnya. Sebelumnya ada kebijakan PSBB dalam menekan angka kasus yang semakin naik, PSBB ini tidak dicabut namun dibuat kebijakan baru yaitu new normal tetapi masih mengikuti sebagaimana protokol kesehatan yang telah ditetapkan. Pemerintah juga tidak tinggal diam dalam menangani kasus pandemi yang sangat berbahaya ini, berbagai macam uapaya pemerintah dalam mengurangi penyebaran Corona virus seperti pemberlakuan kebijakan Pembatasan Sosial Berkala Besar (PSBB) (Harirah, Z., \& Rizaldi, 2020).

PSBB dilaksanakan berdasarkan Peraturan Pemerintah No 21 Tahun 2020. Aturan tersebut menghimbau kepada masyarakat pelaksanaan ibadah, bekerja dan belajar harus dilakukan dirumah dan masyarakat dihimbau untuk menghindari kerumunan masa. Selain itu kebijakan tersebut melarang dilaksanakannya kegiatan yang sifatnya dapat mengundang berkumpulnya masa (Yunus, N. R., \& Rezki, 2020) 
Masa ini dikenal dengan masa pandemi, yang akhirnya membuat krisis di berbagai bidang, termasuk dibidang perekonomian. Banyak bisnis yang sudah mulai menyerah dan menutup kantornya sejak bulan kedua pandemi ini dimulai. Hal ini dibuktikan dengan penurunan pertumbuhan ekonomi Indonesia Berdasarkan perhitungan IMF (International Monetery Fund) di tahun 2020 terjadi penurunan sebanyak $4,5 \%$ dari tahun sebelumnya (Sumarni, 2020).

Penurunan pertumbuhan ekonomi akan memberikan dampak terhadap pelaku bisnis dari berbagai sektor. Hasil survey menunjukan terjadinya penurunan kegiatan pada dunia usaha pada kuartal 1 di tahun 2020 yang disebabkan oleh pandemi (Pakpahan, 2020). Penurunan kegiatan usaha terjadi pada sektor industri seperti sktor pengolahan, perdagangan, perhotelan, dan restoran. Salah satu bisnis yang terkena dampak adalah bisnis restoran cepat saji dimana jumlah konsumen yang berkurang karena kebijakan yang diterapkan pemerintah. Pemerintah menerapkan kebijakan PSBB (Pembatasan Sosial Berskala Besar) sehingga penjualan restoran cepat saji tersebut berkurang. Kerugian yang diterima oleh entitas bisnis diantaranya pendapatan yang rendah namun jumlah pengeluarannya besar seperti pembayaran sewa tempat, upah pekerja bahkan hingga menyebabkan PHK.

Bisnis berbasis Fast Food di Indonesia menunjukkan perkembangan yang cukup pesat selama lima tahun terakhir sebelum terjadinya pandemi. Hal ini terlihat dari pertumbuhan restoran cepat saji di Indonesia cukup banyak. Pada tahun 2016 Direktur Jenderal Perdagangan Dalam Negeri mengatakan diseluruh Indonesia jumlah resatauran waralaba sebanyak 698 jumlah gerai 24.499 dan $40 \%$ adalah restauran cepat saji akan terus meningkat setiap tahunnya (Harwani, 2020). Hal ini menunjukkan adanya intensitas persaingan pada bisnis fast food. persaingan ini membuat para pelaku bisnis harus lebih memperhatikan keinginan konsumen yang beragam, cepat berubah, dan pastinya memiliki nilai kepuasan yang berbeda. Kondisi pandemi saat ini bisnis fast food harus menyesuaikan dengan kebijakan pemerintah. Bentuk pencegahan yang dilakukan oleh restoran cepat saji diantaranya Jumlah pengunjung yang dibatasi, menjalankan protokol kesehatan dan menjaga higienitas restoran.
Kebijakan pembatasan sosial dan work from home menyebabkan kegiatan usaha dibatasi dan kian merosot. Hal tersebut, membutuhkan strategi bisnis agar pendapatan tetap bertahan (survive) di tengah pandemi Covid-19. Strategi bisnis merupakan suatu rangkaian usaha yang dilakukan oleh perusahaan dengan menawarkan produk atau jasa dan merencanakannya secara jangka panjang serta di implementasikan dengan kebijakan yang berlaku agar tetap mendapatkan laba (Wardani, Y. K., Mangunwihardjo, S., \& Perdhana, 2016). Salah satu restoran cepat saji yang telah melaksanakan kebijakan tersebut dan melakukan strategi bisnis adalah restoran Burger King.

Burger King adalah salah satu bisnis fast food yang telah berkembang dan tersebar di berbagai wilayah di Indonesia. Burger King sebagai salah satu bisnis yang berada di level persaingan yang ketat bersaing dengan restauran fast food lainnya. Burger King mampu bersaing dengan restoran fast food lainnya karena membuat produk baru dalam jumlah tidak terlalu banyak dan berkala serta meningkatkan pelayanan konsumen yang baik, bahkan Burger King menurunkan harga untuk pembeli franchise (Sanjiwani, 2015).

Burger King merupakan produk makanan cepat saji khas luar negeri, sehingga citarasanya pun berbeda dengan citarasa makanan lokal. Oleh karena itu, perusahaan Burger King menyesuaikan cita rasa dengan lidah Indonesia seperti membuat beef burger dengan rasa rendang dan menyajikan menu dengan nasi. Bahkan untuk beberapa waktu perusahaan Burger King memberikan harga promo kepada konsumen untuk menarik minatnya. Pada Tahun 2017 untuk memperingati hari kemerdekaan Indonesia Burger King menyediakan menu andalan yaitu beef rusher cheese dikolaborasikan dengan rasa balado atau cabe ijo. Perpaduan budaya barat dan budaya nusantara dalam suatu citarasa merupakan usaha dari perusahaan Burger King untuk melakukan glokalisasi dan menarik minat konsumen lokal. Glokalisasi adalah suatu konsep pandangan hibridasi budaya atau mengkombinasikan budaya agar dapat beradaptasi dengan masyarakat lokal. Penerapan hibridasi dan pendekatan budaya dalam glokalisasi pada Burger King tidak hanya diterapkan pada produk tetapi diterapkan pula pada situasi kondisi Indonesia, adat dan kebiasaan Indonesia, dan keyakinan di Indonesia (Zubair, F., \& Ramdan, 2017) 
Selama pandemi omset penjualan Burger King mengalami penurunan. Perusahaan Burger King awalnya mengalami kenaikan grafik penjualan, jumlah penghasilan rata-rata pada bulan ke-12 dari tahun 2016-2019 terjadi kenaikan namun di tahun 2020 terjadi penurunan dan hanya mencapai $\$ 5.210$ Bilion. Bahkan di triwulan tahun 2020 pendapatan di tahun 2020 terjadi penurunan drastis hingga \$1.048B diseluruh dunia:
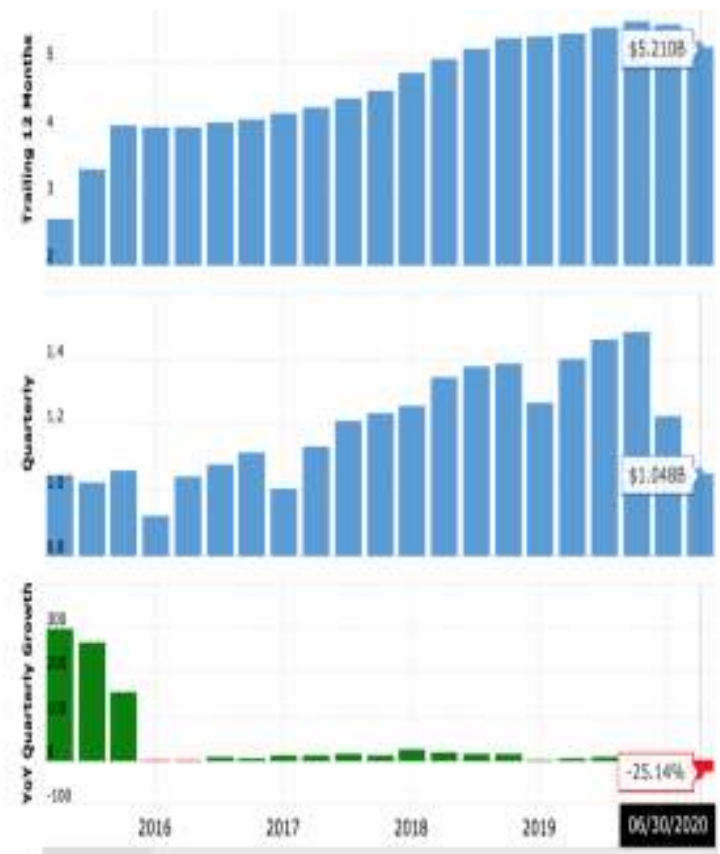

Gambar 1.1

\section{Keputusan Pembelian Konsumen}

Keputusan pembelian yang dilakukan oleh konsumen adalah hal yang kompleks dan harus diamati dari berbagai sudut pandang. Keputusan pembeli dipengaruhi oleh kemampuan perusahaan menarik minat konsumen. Pertanyaan yang harus terjawab oleh konsumen dalam mengambil keputusan sudut pandang $5 \mathrm{~W}+1 \mathrm{H}$. Pertanyaan tersebut diantaranya Dimana produk dapat dibeli, oleh siapa produk itu dibeli, kapan konsumen dapat membeli produk, kenapa konsumen harus membeli produk, dan bagaimana konsumen dapat membeli produk. Konsumen melalui tahap memutuskan membeli produk atau tidak berdasarkan pertimbangan yang telah ditentukan oleh konsumen (Kotler \& Armstrong, 2018)

Konsumen melalui proses pengambilan keputusan ketika membeli produk atau menggunakan jasa. Konsumen merasa tertarik, ingin mencoba dan menggunakan dengan suatu produk hingga muncul rasa ingin memiliki dan ingin membeli produk tersebut, kemudian konsumen mengambil keputusan untuk membeli atau tidak, itulah yang disebut keputusan pembelian (Kotler \& Armstrong, 2018). Produsen akan melakukan berbagai strategi penjualan agar konsumen dapat mengambil keputusan untuk membeli produknya dengan berbagai penawaran.

Dalam mengambil keputusan pembelian oleh konsumen dipengaruhi berbagai karakteristik seperti karakteristik culture, sociology dan phisicology (Pasaribu, 2015). Faktor sosial dipengaruhi oleh hubungan dengan suatu kelompok, perilaku keluarga, dan status konsumen dalam lingkungannya. Tidak dapat dipungkiri, ketertarikan akan suatu brand karena menarik perhatian juga menjadi salah satu faktor eksternal pengambilan keputusan konsumen. Hal yang menarik dari suatu brand seperti identitas atau citra brand tersebut, dan strategi penjualan brand tersebut (Nurmadina, 2016). Selain itu dalam mengambil keputusan untuk membeli juga dikaitkan dengan kualitas layanan yang diberikan.

Penelitian yang dilakukan oleh Aiyun Xiao, Shohua Yang dan Qaisar Iqbal pada tahun 2018 menunjukan bahwa kualitas makanan, kualitas layanan, harga dan lingkungan restoran menjadi faktor yang penting dalam keputusan dan niat membeli. Selain itu penelitian yang dilakukan oleh Anuja Majmundar, Barbara Baquero, Christine B. Williams, dan Lana A. Castro pada tahun 2018 menunjukan bahwa strategi pemasaran yang dilakukan dengan menerapkan faktor harga dan promosi dapat mempengaruhi perilaku pelanggan dengan pengambilan keputusan dalam membeli makanan di toko tersebut. Selanjutnya penelitian yang dilakukan oleh Etty Susilowati dan Agatha Novita Sari pada tahun 2020 menunjukkan bahwa hubungan antara kesadaran merk, asosiasi merek, dan kualitas yang diberikan berhubungan positif dan signifikan. Hal tersebut menandakan konsumen puas dengan produk dan layanan dari Richesee Factory Jakarta.

Proses pengambilan keputusan melalui beberapa tahapan, antara lain identifikasi masalah, keputusan pembelian, pilihan evaluasi, pencarian informasi, dan perilaku pasca pembelian (Kotler \& Armstrong, 2018). Konsumen memiliki masalah yang terjadi misalnya konsumen merasa lapar dan ingin mengonsumsi suatu makanan yang cepat dan enak hal tersebut dengan tahap pengenalan masalah 
Tahap selanjutnya konsumen akan mencari informasi makanan yang disajikan secara cepat ternyata Burger memiliki rasa varian Indonesia seperti rendang dan sambal ijo melalui iklan yang di tayangkan di tv dan terdapat promo bagi pembeli, tahap tersebut merupakan tahap evaluatif alternatif. Dengan pertimbangan harga promo dan cita rasa yang baru konsumen memutuskan untuk membeli produk Burger King tersebut. Setelah diperoleh produk tersebut dan mencobanya konsumen akan mengevaluasi dan memutuskan untuk membeli lagi atau hanya sekedar mencoba produk saja. Jika produk sesuai dengan ekspetasi pembeli kemungkinan besar pembeli akan memutuskan untuk membeli lagi produk. Hal ini lah yang disebut dengan tahap perilaku pasca pembelian.

\section{Identitas Brand}

Idetitas brand atau brand identity adalah suatu nama yang menggambarkan janji kepada konsumen. Identitas brand perlu untuk berresonasi dengan konsumen agar menjadi efektif. Identitas brand juga merupakan sesuatu yang menjadi pembeda dengan merek perusahaan lain dan menggambarkan suatu kegiatan yang akan dilakukan oleh organisasi suatu perusahaan kedepannya.

Identitas brand perlu adanya elemen brand yang digambarkan melalui visual atau fisik untuk mengidentifikasikan suatu barang, jasa, atau produk. Elemen tersebut dapat berupa nama, logo, dan slogan yang menggambarkan keunikan atau perbedaan suatu perusahaan dengan perusahaan lainnya (Kotler, P., \& Pfoertsch, 2008).

Sebuah brand atau biasa kita sebut dengan merek adalah membedakannya dari produk atau jasa lain untuk memberikan produk atau jasa dengan kepuasan yang berbeda-beda (Kotler \& Keller, 2013). Identitas brand terdiri dari logo, gambar, slogan yang menggambarkan citra perusahaan. Adanya identitas brand memberikan persepsi yang khas dari perusahaan untuk konsumen agar dapat mengenal suatu produk yang telah ditawarkan kualitasnya. Brand adalah petunjuk yang digunakan oleh konsumen.

Setiap perusahaan pasti memiliki brand. Dalam meningkatkan reputasi suatu brand adalah hal yang tidak mudah. ada beberapa strategi yang harus diperhatikan ketika ingin meningkatkan suatu brand, yaitu sebagai berikut: a. Barang harus berkesan dan unik

b. Konsisten dalam meningkatkannya

c. Brand tidak boleh sama dengan perusahaan lain

d. Berhubungan atau Interaksi

e. Komunikasi dilakukan secara langsung

Citra brand akan mempresentasikan asosiasi yang ada dalam pikiran seseorang saat berpikir tentang brand tertentu (Morissan, 2015). Asosiasi ini dapat berupa jenis, kebaikan, kekuatan, atau bahkan keunikan suatu merek. Faktor pembentuk citra merek adalah sebagai berikut (Haryono \& Octavia, 2020):

1. Manfaat

2. Dapat diandalkan

3. Kualitas atau mutu

4. Pelayanan

5. Harga

6. Resiko

7. Citra dari merek itu sendiri.

\section{Strategi Penjualan (Pemasaran)}

Strategi pemasaran merupakan suatu langkah yang digunakan untuk memenangkan persaingan pasar secara berkelanjutan yang digunakan oleh perusahaan produk atau jasa (Tjiptono \& Fandy, 2015). Strategi pemasaran merupakan suatu pola pikir pemasaran yang diupayakan untuk mencapai suatu target dan tujuan. Dalam strategi pemasaran terdapat rincian mengenai pasar sasaran, menentukan posisi, penyebaran pemasaran dan biaya yang dibutuhkan dalam pemasaran.

Dalam memutuskan memilih strategi pemasaran sudah melalui proses yang panjang. karena strategi pemasaran bisa dilihat berdasarkan dari berbagai sudut pandang seperti alur dalam mencari cara dalam melakukan pemasaran. elemen program pemasaran dalam siklus hidup produk harus disesuaikan dengan tahapan perkenalan, pertumbuhan, dan situasi kondisi. Hal ini berlaku pula pada konteks posisi persaingan secara kompetisi. Strategi pemasaran secara kompetisi dirancang berdasarkan posisi kompetisi setiap perusahaan. Hal tersebut, dianalisis berdasarkan 4 dimensi utama yaitu posisi struktural, posisi strategi, posisi pasar, dan posisi sumber(Abdurrahman, 2015). Faktor hal yang harus diperhatikan dalam mengambil keputusan strategi pemasaran secara cermat dan terperinci adalah faktor-faktor seperti, peluang yang dimiliki pasar, tujuan atau target produk serta keberhasilan pasar (Suranta, 2015). Selain itu, mempersiapkan 
segala konsekuensi yang akan diterima pada saat pemasaran maupun setelah pemasaran itu dilakukan. Strategi yang dapat menarik minat konsumen yaitu perusahaan harus mengetahui kebutuhan, keinginan konsumen, dan sasaran pasar yang efektif dan efisien untuk menghadapi pesaing. Dalam penelitian ini rumusan masalah yang diuraikan berdasarkan latar belakang masalah diantaranya:

1. Apakah Identitas Brand Burger King berpengaruh terhadap keputusan pembelian konsumen selama masa pandemi Covid 19?

2. Apakah perubahan strategi penjualan Burger King berpengaruh terhadap keputusan pembelian konsumen selama masa pandemi Covid 19?

\section{Tujuan Penelitian}

Tujuan penelitian disusun untuk menjelaskan rumusan masalah yang telah ditentukan:

1. Untuk menganalisis pengaruh Identitas Brand Burger King terhadap keputusan pembelian konsumen selama masa pandemi Covid 19.

2. Untuk menganalisis pengaruh perubahan strategi penjualan Burger King terhadap keputusan pembelian konsumen selama masa pandemi Covid 19?

\section{Hipotesis Penelitian}

1. Identitas brand yang dimiliki Burger King berpengaruh terhadap keputusan pembelian konsumen selama masa pandemi Covid 19

2. Perubahan strategi penjualan Burger King berpengaruh signifikan terhadap keputusan pembelian konsumen selama masa pandemi Covid 19.

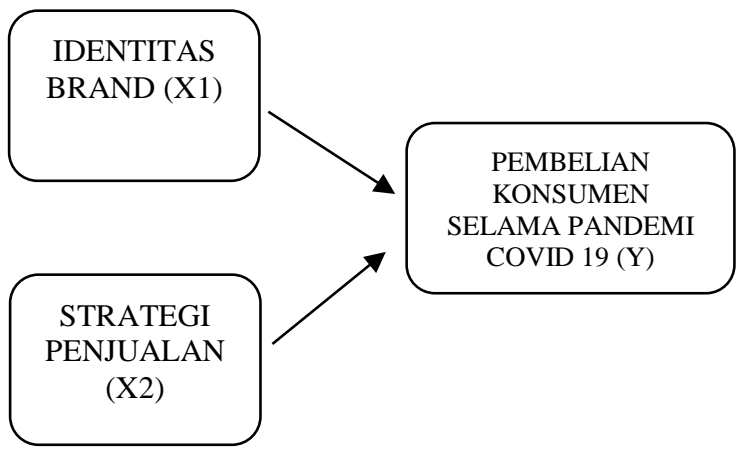

\section{METODOLOGI PENELITIAN}

Metode kuantitatif dengan jenis Metode kuantitatif dengan jenis penelitian deskriptif digunakan dalam penelitian ini yang akan dilakukan kepada para konsumen Burger King. Proses penelitian yang dilakukan untuk menemukan suatu pengetahuan dengan memanfaatkan data dalam bentuk angka disebut dengan penelitian kuantitatif.

Wilayah generalisasi yang ditentukan oleh peneliti terhadap suatu subyek atau obyek hingga diperoleh suatu kesimpulan disebut dengan populasi (Sugiyono, 2017). Populasi adalah suatu kelompok orang yang menarik yang ingin diteliti . Kelompok orang tersebut menjadi salah satu bahan untuk diteliti hingga diperoleh suatu kesimpulan. Penelitian ini populasinya adalah konsumen Burger King. Apabila peneliti memiliki keterbatasan biaya dan waktu maka peneliti cukup menggunakan sebagian dari populasi yang digunakan sebagai sampel yang dapat benarbenar terwakili. Oleh karena itu, jumlah konsumen yang banyak dan beragam sehingga peneliti menentukan kriteria untuk menentukan populasi yaitu ditujukan kepada konsumen dengan minimal tiga kali kunjungan atau pembelian produk Burger King baik itu dalam bentuk take away, dine in, ataupun drive thru.

Berdasarkan populasi yang telah ditentukan diambil beberapa anggota terpilih yang termasuk dari bagian populasi disebut dengan sampel. Jumlah sampel ditentukan dari minimum sepuluh kali jumlah pertanyaan yang dianalisis (Sekaran, 2016). Dalam penelitian ini terdapat 21 pertanyaan pada kuesioner sehingga minimum jumlah sampel yang dibutuhkan adalah 105 responden (21 pertanyaan x 5).

Teknik yang dilakukan oleh peneliti dalam mengumpulkan data adalah dengan menggunakan metode survey melalui penyebaran kuesioner. Penyebaran kuesioner adalah cara pengumpulan data dengan memberikan pertanyaan atau pernyataan kepada responden guna memperoleh hasil penelitian (Sugiyono, 2017). Kuesioner adalah bentuk pernyataan yang terstruktur dan diberi tanggapan oleh konsumen Burger King. Penelitian menggunakan kuesioner peneliti dapat memperoleh data secara terperinci karena pernyataan dilakukan secara jelas dan peneliti dapat mengontrol pernyataan yang diberikan kepada responden. Hasil tanggapan konsumen dikumpulkan hingga diperoleh data dan dihitung menggunakan kuantitatif sesuai dengan skala yang telah ditentukan. Skala pengukuran menggunakan skala likert berisi tujuh poin pernyataan yaitu 
$1=$ Sangat tidak setuju sekali

2 = Sangat tidak setuju

3 = Tidak setuju

4 = Cukup setuju

$5=$ Setuju

$6=$ Sangat setuju

7 = Sangat setuju sekali

Kuesioner yang diberikan kepada responden sudah terdapat jawabannya, responden hanya memilih pilihan jawaban yang disediakan sesuai dengan pertimbangan pribadi responden, hal ini disebut dengan kuesioner tertutup. Kemudian hasil data kuantitatif tersebut dideskripsikan melalui penelitian deskriptif dan dihubungkan dengan masalah masalah yang terjadi selama masa Covid 19 yang mempengaruhi pembelian dari Burger King.

Variabel yang digunakan dalam penelitian ini mengunakan variabel dependen dan independen. Variabel independen atau variabel bebas adalah variabel yang dapat mempengaruhi variabel dependen atau variabel terikat. Variabel independen dalam penelitian ini adalah identitas brand (X1) dan Strategi Penjualan (X2). Sedangkan variabel dependennya adalah pembelian konsumen selama pandemi Covid-19 (Y). Sedangkan Variabel terikat atau veriabel dependen dipengaruhi oleh variabel bebas atau variabel independen. Metode analisis data yang digunakan dalam penelitian ini yaitu menggunakan metode analisis deskriptif yaitu menjelaskan hasil penelitian secara deskripsi, uji validitas untuk menentukan kelayakan instrumen penelitian, uji reliabilitas, uji regresi linear berganda, uji koefisien determinasi, Uji F dan Uji t.

\section{HASIL DAN PEMBAHASAN}

Pada penelitian ini, telah disebarkan 105 kuesioner kepada konsumen Burger King yang pernah mengunjungi atau membeli produk secara langsung maupun tidak langsung. Semua kuesioner disebarkan atau dibagi secara online menggunakan google forms yang diisi oleh para responden. Dari total 105 responden, dapat diketahui profil responden terdapat $57(54,3 \%)$ pria dan $43(45,7 \%)$ wanita yang mengisi responden.

Sedangkan dari segi rentang usia, $<15$ tahun terdapat 3 responden $(2,85 \%), 15-18$ tahun terdapat 13 responden $(12,4 \%), 19-22$ tahun terdapat 82 responden $(78,1 \%)$ dan $>22$ tahun terdapat 7 responden $(6,7 \%)$.
Tabel 1.

Hasil Uji Reliabilitas

\begin{tabular}{|c|c|c|c|}
\hline Variabel & $\begin{array}{c}\text { Cornbach' } \\
\text { s Alpha }\end{array}$ & Items & Keterangan \\
\hline $\begin{array}{c}\text { Brand } \\
\text { Identity }\end{array}$ & .886 & 5 & Reliabel \\
\hline $\begin{array}{c}\text { Strategi } \\
\text { Penjualan }\end{array}$ & .895 & 7 & Reliabel \\
\hline $\begin{array}{c}\text { Keputusan } \\
\text { Pembeli }\end{array}$ & .888 & 7 & Reliabel \\
\hline
\end{tabular}

Sumber : Hasil Olahan Data SPSS (2020)

Dari Tabel 1 cornbach's alpha menunjukkan bahwa tiap variabel lebih besar dari 0,6 yang berarti reliabel. Nilai Cornbach's alpha untuk variabel Brand Identity, Strategi Penjualan dan Keputusan Pembeli masing-masing adalah 0,886, 0,895 , dan 0,888 .

Tabel 2.

Hasil Uji Validitas Brand Identity

\begin{tabular}{|l|r|c|c|}
\hline Variabel & $\begin{array}{c}\text { Scale } \\
\text { Item if } \\
\text { Deleted }\end{array}$ & $\begin{array}{c}\text { If Scale } \\
\text { if Item }\end{array}$ & $\begin{array}{c}\text { Corrected } \\
\text { Item- } \\
\text { Total } \\
\text { Correlati } \\
\text { on }\end{array}$ \\
\hline BI1 & 23.82 & 13.169 & .449 \\
\hline BI2 & 24.47 & 11.617 & .480 \\
\hline BI3 & 24.05 & 11.488 & .597 \\
\hline BI4 & 24.41 & 10.167 & .643 \\
\hline BI5 & 24.25 & 10.784 & .539 \\
\hline
\end{tabular}

Sumber: Hasil Olahan Data SPSS (2020)

Pada Tabel 2 dapat dilihat bahwa nilai Corrected item-total correlation dari seluruh indikator Brand Identity adalah lebih dari 0.3. sehingga dapat dikatakan bahwa semua indikator atau butir pertanyaan dari indikator tersebut dinyatakan valid. 
Tabel 3.

Hasil Uji Validitas Strategi Penjualan

\begin{tabular}{|l|r|r|r|}
\hline Variabel & $\begin{array}{c}\text { Scale } \\
\text { Mean if } \\
\text { Item } \\
\text { Deleted }\end{array}$ & $\begin{array}{c}\text { If Scale if } \\
\text { Item } \\
\text { Deleted }\end{array}$ & $\begin{array}{c}\text { Corrected } \\
\text { Item-Total } \\
\text { Correlation }\end{array}$ \\
\hline SP1 & 31.54 & 52.366 & .770 \\
SP2 & 31.56 & 53.710 & .743 \\
SP3 & 31.81 & 49.675 & .674 \\
SP4 & 31.43 & 49.363 & .873 \\
SP5 & 31.47 & 53.463 & .784 \\
SP6 & 31.68 & 53.510 & .734 \\
SP7 & 31.43 & 53.459 & .781 \\
\hline
\end{tabular}

Sumber : Hasil Olahan Data SPSS (2020)

Pada Tabel 3 dapat dilihat bahwa nilai Corrected item-total correlation dari seluruh indikator Strategi Penjualan adalah lebih dari 0.3. sehingga dapat dikatakan bahwa semua indikator atau butir pertanyaan dari indikator tersebut dinyatakan valid.

Tabel 4.

Hasil Uji Validitas Keputusan Pembelian

\begin{tabular}{|c|r|r|r|}
\hline $\begin{array}{c}\text { Variabe } \\
1\end{array}$ & $\begin{array}{c}\text { Scale } \\
\text { Mean if } \\
\text { Item } \\
\text { Deleted }\end{array}$ & $\begin{array}{c}\text { If Scale } \\
\text { if Item } \\
\text { Deleted }\end{array}$ & $\begin{array}{c}\text { Corrected } \\
\text { Item-Total } \\
\text { Correlation }\end{array}$ \\
\hline KP1 & 31.71 & 47.187 & .761 \\
\hline KP2 & 31.50 & 49.233 & .775 \\
\hline KP3 & 31.97 & 46.855 & .792 \\
\hline KP4 & 31.87 & 47.213 & .772 \\
\hline KP5 & 31.52 & 50.290 & .742 \\
\hline KP6 & 31.59 & 47.186 & .808 \\
\hline KP7 & 31.78 & 46.403 & .816 \\
\hline
\end{tabular}

Sumber: Hasil Olahan Data SPSS (2020)

Pada Tabel 3 dapat dilihat bahwa nilai Corrected item-total correlation dari seluruh indikator Strategi Penjualan adalah lebih dari 0.3. sehingga dapat dikatakan bahwa semua indikator atau butir pertanyaan dari indikator tersebut dinyatakan valid.

Tabel 5.

Hasil Uji Regresi Linier Berganda

\begin{tabular}{|c|c|c|c|c|}
\hline \multirow{3}{*}{ Model } & \multicolumn{2}{|c|}{$\begin{array}{c}\text { Unstandardized } \\
\text { Coefficients }\end{array}$} & $\begin{array}{c}\text { Standardized } \\
\text { Coefficients }\end{array}$ & \multirow{2}{*}{ Sig. } \\
\cline { 2 - 4 } & B & Std. Error & Beta & \\
\hline
\end{tabular}

\begin{tabular}{|c|r|r|r|l|}
\hline (Constant) & -.034 & 3.689 & & .993 \\
\hline BI & .428 & .127 & .220 & .001 \\
\hline SP & .654 & .062 & .683 & .000 \\
\hline
\end{tabular}

a. Dependent Variable: Keputusan Pembelian Sumber: Hasil Olahan Data SPSS (2020)

Rumusan persamaan regresi berganda di atas, sebagai berikut:

$$
\begin{aligned}
& \mathrm{Y}=\alpha+\beta 1 \mathrm{X} 1+\beta 2 \mathrm{X} 2+\mathrm{e} \\
& \mathrm{Y}=-0.034+0.428 \mathrm{BI}+0.654 \mathrm{P}+\mathrm{e}
\end{aligned}
$$

Persamaan ini menggambarkan bahwa:

a. Konstanta (a) $=-0.034$, artinya jika Brand Identity (X1) dan Strategi Penjualan (X2) tidak mengalami perubahan atau sama dengan 0 maka besarnya Keputusan Pembelian (Y) adalah -0.034 sebagai satu kesatuan.

b. Jika variabel Brand Identity (X1) mengalami perubahan sebesar 1 satuan, sementara variabel Strategi Penjualan (X2) tetap atau sama dengan 0 , maka keputusan pembelian (Y) akan mengalami peningkatan sebesar 0,428 satuan.

c. Jika variabel Strategi Penjualan (X2) mengalami perubahan sebesar 1 satuan, sementara variabel Brand Identity(X1) tetap atau sama dengan 0 , maka keputusan pembelian (Y) akan mengalami peningkatan sebesar 0, 654 satuan.

Tabel 6.

Koefisien Determinasi $\left(\mathrm{R}^{2}\right)$

\begin{tabular}{|c|r|r|r|}
\hline $\mathrm{R}$ & R Square & $\begin{array}{c}\text { Adjusted R } \\
\text { Square }\end{array}$ & $\begin{array}{r}\text { Std. Error of } \\
\text { the Estimate }\end{array}$ \\
\hline $.793^{\mathrm{a}}$ & .629 & .621 & 4.93365 \\
\hline
\end{tabular}

Sumber: Hasil Olahan Data SPSS (2020)

Melalui perhitungan yang dilakukan dengan software SPSS, didapatkan bahwa nilai R sebesar 0.793. Artinya, persamaan model linier berganda di atas mempunyai hubungan yang erat atau kuat. Kemudian nilai adjusted $\mathrm{R}$ square atau koefisien determinasi $\left(\mathrm{R}^{2}\right)$ sebesar 0,621. Hal ini menunjukkan bahwa $62,1 \%$ Keputusan Pembelian di pengaruhi oleh variabel Brand Identity dan Strategi Penjualan sisanya yaitu sebesar $37,9 \%$ dipengaruhi oleh variabel lainnya yang tidak disebutkan di dalam model persamaan regresi.

Tabel 7.

Hasil Uji F

\begin{tabular}{|l|c|c|c|c|c|}
\hline Model & Sum of Squares & df & $\begin{array}{c}\text { Mean } \\
\text { Square }\end{array}$ & F & Sig. \\
\hline $\begin{array}{l}\text { Regressi } \\
\text { on }\end{array}$ & 4202.223 & 2 & $\begin{array}{c}2101.11 \\
1\end{array}$ & $\begin{array}{c}86.3 \\
20\end{array}$ & $.000^{\mathrm{a}}$ \\
\hline Residual & 2482.768 & 102 & 24.341 & & \\
\hline Total & 6684.990 & 104 & & & \\
\hline
\end{tabular}


a. Predictors: (Constant), strategi_penjualan, brand_identity

b. Dependent Variable: keputusan_pembeli Sumber: Hasil Olahan Data (2020)

Pada Tabel 7 di atas dapat dilihat bahwa signifikansi F sebesar 0,000 yang berarti Sig < 0.05 . Hal ini membuktikan bahwa Brand Identity dan Strategi Penjualan berpengaruh Terhadap Keputusan Pembelian. Kemudian F-hitung menunjukkan hasil 86,320. Untuk nilai F-tabel dengan df $1=2$ dan df $2=$ 102 adalah 3,09. Maka F-hitung > F-tabel yaitu $86,320>3,09$ yang berarti menerima H1 dan Ho ditolak, sehingga dapat dikatakan bahwa variabel bebas yaitu brand Identity dan Strategi Penjualan berpengaruh terhadap Keputusan Pembelian konsumen Burger King.

Tabel 8.

Hasil Uji t

\begin{tabular}{|c|c|c|c|c|c|}
\hline \multirow{2}{*}{ Model } & \multicolumn{2}{|c|}{$\begin{array}{l}\text { Unstandardize } \\
\text { d Coefficients }\end{array}$} & $\begin{array}{c}\text { Standa } \\
\text { rdized } \\
\text { Coeffic }\end{array}$ & \multirow{2}{*}{$\mathrm{t}$} & \multirow{2}{*}{ Sig. } \\
\hline & B & $\begin{array}{l}\text { Std. } \\
\text { Error }\end{array}$ & Beta & & \\
\hline (Constar & -.034 & 3.689 & & -.009 & .993 \\
\hline $\mathrm{BI}$ & .428 & .127 & .220 & 3.367 & .001 \\
\hline SP & .654 & .062 & .683 & 10.476 & .000 \\
\hline
\end{tabular}

a. Dependent Variable: Keputusan Pembelian

Sumber: Hasil Olahan Data SPSS (2020)

Pada tabel 8 uji t di atas dapat dilihat bahwa variabel Brand Identity dan Strategi Penjualan secara parsial berpengaruh signifikan terhadap Keputusan Pembelian, hal ini dapat dilihat dari nilai t-hitung $\mathrm{t}=$ $-0,009<\mathrm{t}$-tabel $=1.66$ berarti Ho dapat ditolak dan $\mathrm{H} 1$ diterima. Variabel Brand Identity mempunyai thitung $=3.367>$ t-tabel $=1.66$ dan nilai sig sebesar 0,001 yang artinya sig $<0,05$. Maka, dapat disimpulkan adanya pengaruh signifikan terhadap Keputusan Pembelian.

Kemudian untuk variabel Strategi Penjualan mempunyai nilai t-hitung $=10.476>\mathrm{t}$ tabel $=1.66$ dan nilai sig sebesar 0,000 yang artinya sig < 0,05. Maka, dapat disimpulkan bahwa variabel Strategi Penjualan berpengaruh signifikan terhadap Keputusan Pembelian konsumen Burger King.

\section{KESIMPULAN}

Berdasarkan dari data kuisioner yang telah di isi oleh responden sebanyak 105 orang dari berbagai kalangan usia secara online melalui google form, dapat di simpulkan bahwa semua pertanyaan reliabel dan valid sehingga data tersebut cocok digunakan untuk uji selanjutnya yaitu uji hipotesis dan regresi linier berganda.

Dari hasil uji hipotesis dan analisis regresi yang dilakukan peneliti, menunjukkan bahwa variabel Strategi Penjualan dan Brand Identity memiliki pengaruh yang signifikan terhadap keputusan pembelian Burger king di Indonesia. Artinya berdasarkan dari Brand Identity yaitu kualitas baik yang dimiliki oleh brand itu sendiri dan strategi penjualan yaitu teknik pemasaran, cara mempromosikan penjualan yang dilakukan sangat berpengaruh terhadap pembelian konsumen selama masa pandemic Covid-19.

\section{SARAN}

Maka dari itu ada baiknya jika Burger King di Indonesia lebih berfokus dan meningkatkan dari sisi Strategi Penjualan produk mereka dengan cara yang menarik terutama pada masa covid-19. Memanfaatkan gadget untuk memperkenalkan kualitas produk terhadap publik yang bertujuan untuk memperluas cakupan konsumen. Membangun produk kerja sama yang lebih luas dengan berbagai pihak, sehingga dapat mengembangkan brand serta strategi penjualan dalam satu waktu.

\section{DAFTAR PUSTAKA}

Abdurrahman, N. H. dan A. S. (2015). Manajemen Strategi Pemasaran. In Manajemen Strategi Pemasaran.

Harirah, Z., \& Rizaldi, A. (2020). Merespon Nalar Kebijakan Negara Dalam Menangani Pandemi Covid 19 Di Indonesia. Jurnal Ekonomi Dan Kebijakan Publik Indonesia, 7(1), 36-53.

Harwani, Y. (2020). Keputusan Pembelian Konsumen Gerai Makanan Cepat Saji Ditinjau dari Kualitas Produk, Persepsi Harga dan Iklan Product Quality , Price Perception and Advertising ). Business Economic, Communication, and Social Sciences (BECOSS) Journal, 2(3), 45-51.

Haryono, N., \& Octavia, R. (2020). Analisis Pengaruh Citra Merek Dan Mutu Layanan Terhadap Kepuasan Konsumen Serta Dampaknya Terhadap Loyalitas Konsumen. Haryono, N., \& Octavia, R. (2014). ANALISIS PENGARUH CITRA MEREK DAN MUTU LAYANAN TERHADAP KEPUASAN KONSUMEN SERTA DAMPAKNYA TERHADAP LOYALITAS KONSUMEN. INDEPT, 4(1), 20-27.INDEPT.

Kotler, P., \& Pfoertsch, W. (2008). In B2B brand management. PT. Bhuana Ilmu. 
Kotler, P., \& Armstrong, G. (2018). Kotler \&amp; Armstrong, Principles of Marketing | Pearson. In Pearson.

Kotler, P., \& Keller, K. L. (2013). Manajemen pemasaran Jilid 1. In Jakarta.

Morissan. (2015). Periklanan: Komunikasi Pemasaran Terpadu. In Jakarta: Prenada Media Group.

Nurmadina. (2016). Analisis Faktor-Faktor yang Mempengaruhi Keputusan Pembelian Secara Online. Intekna.

Pakpahan, A. K. (2020). COVID-19 dan Implikasi Bagi Usaha Mikro, Kecil, dan Menengah. Jurnal Ilmiah Hubungan Internasional, 20(April).

Pasaribu, R. B. F. (2015). Jurnal Riset Manajemen Dan Bisnis. Jurnal Riset Manajemen \& Bisnis.

Sanjiwani, S. (2015). Analisis Kepuasan Konsumen Restoran Cepat Saji Menggunakan Metode Partial Least Square (Studi Kasus: Burger King Bali). E-Jurnal Matematika, 4(3), 98. https://doi.org/10.24843/mtk.2015.v04.i03.p09 5

Sekaran, U. dan B. R. (2016). Research Methods for Business. In Wiley. https://doi.org/10.1007/978-94-007-07535_102084

Sugiyono. (2017). Metode Penelitian Bisnis (Pendekatan Kuantitatif, Kualitatif, Kombinasi dan R\&D). In Metodelogi Penelitian.

Sumarni, Y. (2020). Pandemi Covid-19: Tantangan Ekonomi Dan Bisnis. Jurnal Ekonomi Dan Perbankan Syariah, 6(2), 46-58.

Suranta, G. F. (2015). Analisis Strategi Pemasaran Jasa Menghadapi Pesaing. Analisis Strategi Pemasaran Jasa Menghadapi Pesaing.

Tim COVID-19 IDAI. (2020). Protokol Tatalaksana Covid-19. 1 .

Tjiptono, \& Fandy. (2015). Strategi Pemasaran. In Yogyakarta: Andi.

Wardani, Y. K., Mangunwihardjo, S., \& Perdhana, M. S. (2016). Membangun Strategi Bisnis melalui Faktor Manajerial sebagai Pemilik dan Lingkungan Bisnis Eksternal dalam Meningkatkan Kinerja Perusahaan (Studi pada UKM makanan di Kota Semarang).
Yunus, N. R., \& Rezki, A. (2020). Kebijakan Pemberlakuan Lock Down Sebagai Antisipasi Penyebaran Corona Kebijakan Pemberlakuan Lockdown Sebagai Antisipasi Penyebaran Corona Virus Covid-19 $\square$. Salam: Jurnal Sosial Dan Budaya Syar-I, 7(3)(April), $227-$ 238. https://doi.org/10.15408/sjsbs.v7i3.15083

Zubair, F., \& Ramdan, A. T. M. (2017). Penerapan Glokalisasi dan Konsep Hirbidisasi Budaya dalam Komunikasi Pemasaran Burger King di Indonesia. In BMC Public Health (Vol. 5, Issue 1, pp. 1-8). 